\title{
A STUDY OF MUTHUSWAMI DIKSHITAR'S EXPERTISE ON VARIOUS ELEMENTS OF MUSICOLOGY REFLECTED THROUGH HIS COMPOSITIONS
}

\author{
Utpala Karanth ${ }^{1 凹}$ (iD), Dr. Ramkrishna Rangan ${ }^{2} 凹$ (iD) \\ Pursuing PHD at SVYASA University, Yoga and Spirituality Division, Swami Vivekananda University [S- \\ VYASA], Bangalore, India \\ ${ }^{2}$ Visiting Professor at SVYASA University, Bangalore, India
}

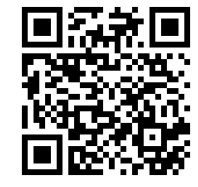

Received 06 September 2021

Accepted 05 October 2021

Published 14 November 2021

\section{CorrespondingAuthor \\ Utpala Karanth, \\ utpalakaranth16@gmail.com}

\section{DOI}

10.29121/shodhkosh.v2.i2.2021.43

Funding: This research received no specific grant from any funding agency in the public, commercial, or not-for-profit sectors.

Copyright: (C) 2021 The Author(s). This is an open access article distributed under the terms of the Creative Commons Attribution License, which permits unrestricted use, distribution, and reproduction in any medium, provided the original author and source are credited.

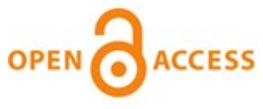

\section{ABSTRACT}

Musicology is the study of scientific and intellectually handling of music. This is a colossal subject of music and inquest into the History and phenomenon of music including life and works of Composers and performers, music theory like melody, rhythm, harmony, modes, aesthetics, form etc. The Historical evidence of Indian Classical music have been discussed in several ancient texts like Veda's, Upanishads, epics way back 2000 years ago. The Rigveda, Yajurveda, Samaveda and Atharvaveda contains ritual hymns and incantations (vedic chants), praising the specific dieties during the Sacrificial rituals. The South Indian music has a phlegmatic and pedagogic nature when compared with the music of other unconsecrated Hindustani traditions. This paper highlights the proficiency of Dikshitar's knowledge of Musicology bequeathed from his father Ramaswami Dikshitar, a scholar, musician, learned musicologist, and recipient of many honours and emoluments in the knowledge of music gained sufficient knowledge in musicology who had settled down at Tiruvarur where Dikshitar was born. Tiruvarur then was a seat of learning of Sanskrit and Vedanta. Dikshitar's compositions reflect his deep and thorough knowledge widely through the interpretation of their literature as seen in famous compositions like 'Vatapi Ganapatim Bhaje', 'Amrutavarshini' and others will be discussed with the various rasas created through the ragas as enunciated in the Natyashastra of Bharat Muni.

Keywords: Raga, Bhava, Tala, musicology, Dikshitar

\section{INTRODUCTION}

Carnatic Music is well known for its diversity of Ragas, Talas and sangatis. No other music in the world has such a variety. In this, the contribution of the musical trinity Tyagaraja, Shyama Shastri, Muthuswami Dikshitar excels. Dikshitar maintained his sublimated personality and elevated himself to an impersonal level by maintaining an indifferent or cool attitude to any situation. The various moods of the personality of an artist can influence the expressions of Art. This psychological behaviour provides the exact explanation for the majestic, striking richness, overall completeness, perfectly formed musical compositions so his kritis took the impersonal Art form with Shanta rasa and sthayi bhava to the core. The legendary musicologists enunciated in his famous work 'Natyashastra'; 'human voice is the first instrument that can rebalance, rewire, and influence the mind and bring back its bright essence and open inner energies'. The Music integrates with the metaphysical phenomena to escape 
from the gross form, towards the supreme. This paper is to cull the various gems or components of music dealt by Dikshitar in his compositions and to detail the connectivity of emotions and tunes adopted by Dikshitar Srivatsa (1995)

\section{LITERATURE SEARCH}

Several authors have researched the music of Dikshitar. Shivashankari (2015) discusses various musical components adopted by Dikshitar like Swarakshara, yamakalakara, prasa and sharabha prasa (Shivashankari (2015)).

Sreeranjini. M. (2010) discusses Dikshitar's contribution to Hindusthani and western music too and talks about the new Ragas popularized by Dikshitar. She deals with several talas, Sangatis and Prasa's used by Dikshitar. She deals with Ragas of Dikshitar's and Ragamalika's Sreeranjini (2010).

Srilekha (2016) deals with Dikshitar's style of Vilambakala or slow tempo. She describes his uniqueness as his choice of single but elaborate Charana format for his kriti's, providing a slow tempo structure, to offer ample scope for the purpose. She analyses many compositions of Dikshitar in the light of musical criticism Srilekha (2016), Sreeranjini (2010)

Srivatsa (1995) has dealt with the connections of various ragas adopted by Dikshitar with various emotions which becomes the main topic of this paper Srivatsa (1995) .

This paper is to deal in detail on what musical components Dikshitar talks about in his compositions and to detail the connectivity of emotions and tunes that Dikshitar has adopted.

\section{METHODS}

Searching for the components of the music, and the terms that are directly related to music and musicology through the passages in Dikshitar's compositions. Dealing the connections between several emotions with ragas adopted by Dikshitar and with his literature with the help of musicologists and one's own experience.

\section{AREA OF STUDY}

Dikshitar's compositions are analysed, and the literature is interpreted to reveal the various components of musicology and which emotions are created basing on the ragas through the compositions.

\section{Spirituality and music}

Indian classical music and its ancient tradition of Ragas is a classical model for practicing Bhakti Yoga (Yoga of devotion). Bhakti Yoga involves experiencing the subtle vibrations caused by the internal music and sounds of the body. While Meditating on the tones, a practitioner can attain a state of complete silence and peace that leads to access to inner sentiments and thoughts. According to Bhajana Sampradaya (tradition of spiritual singing of south India), singing and praising Gods and Goddesses is the ritual which reflects in Dikshitar's compositions Govindarao (1997) 


\section{Association of music with Gods and Goddesses}

Several religious faiths discard music. They believe that music is against spiritual growth. They also believe that music may make one fall in lower emotions so that one falls from spirituality. But Most of the faiths and traditions of India not only accept music in spirituality but also uses it to culture the emotions. This is how ancient Tamil Music, Carnatic Music, and Hindusthani were born. Above all at the very beginning of Indian history, Samaveda is musical. Dikshitar connects it with Divinity.

\section{Sadāśivaṁ sāmagāna vinutaṁ}

He is Sadashiva, extolled by Sāmaveda (471-C)(Caraṇam) Govindarao (1997) .

Dikshitar not only knows music as against spirituality but also always connects it with spirituality. Dikshitar talks about how Gods and Goddesses are fond of music.

\section{Guruguham san்gitapriyam் bhajeham}

I sing on lord Guruguha who is fond of music (425-P)(Pallavi).

\section{Gītavādyapriye}

Oh, Ganga! You are fond of music both vocal and instrumental (225-P).

\section{The root Bhaja}

Dikshitar uses the root Bhaja in hundreds of places. E.g.

\section{Śrī sundararājaṁ bhajeham}

I sing on lord Sundararaja (392-P).

\section{Paramaśivātmajaṁnamāmisatatam sadābhajeham்}

I worship the son of lord Paramashiva (456-P).

\section{Acyutādim bhajehammaniśam}

I constantly sing on Varavenkatesham also called Acyutā (469-10 th stanza).

Though Bhaja has several meanings like serving and experiencing and though all these meanings can be applied in these compositions, it is taken here as singing here. Dikshitar being a great musician must have used this word mainly for this purpose, though he does not discard other meanings. Throughout India 'Bhaja' is used mainly for singing on God. E.g Bhasani in Tamil, Bhajan in Hindi, Bhojon in Bengali etc.

Dikshitar had sung many songs for all Gods of the Hindu pantheon. Surprisingly he has sung on Brahma too. Generally, nobody sings on Brahma in Hindu traditions, though he is a vital God. There is a belief in the Vedic tradition that Brahma has to be only meditated and should not be extolled by lips, as he is beyond words. Brahmānạmmanasādhyāyet | But here is a wonderful song on Brahma by Dikshitar which is the only one song attributed to him in Hindu traditions.

$$
\text { Bhūṣāpatim mañjubhāṣāpatim bhajeham śeșānga }
$$

śayananutam aśeșadevasannutam

virātsvarūpākāram viśvasrșțikarttāramparāśarādyupacāram paramādvaitavicāraṁ virājamāna śarīram vedavedāntasāram dharādibhūtādhāram dhātāram maṇihāraṁ purandarādyadhikāram pūrṇaphaladātāram sarojāsanaṁ dhīram̉ sadguruguhapracāram் 
I sing on lord Bhushapati (Brahma), the lord of Goddess Sarasvati. He is extolled by lord Vishnu and other Gods. He created the Universe and reflected upon the Advaita system of philosophy. He has a lustrous body and is the essence of the Veda and Upaniśads. He is the substratum for the five elements such as Earth. He is the master of Indra and is seated on a Lotus (427-P, AP, C).

\section{Internal melody}

Dikshitar addresses his mind and advises it to get engaged in Bhajanam. Dikshitar addresses Manas (mind), Citta (psyche), and Hṛdaya (heart) in several songs. Manas is that which contemplates. Citta is the seat of all thoughts. Hridaya is the repository of experience. This can be interpreted as his advice of serving, extolling, singing, adoring, and experiencing as Bhaja has all these meanings. As the mind is addressed and advised here, this can be taken as the fusion of Smarana (contemplation) and Kīrtana (singing).

\section{Kanakasabhāpatim bhajare mānasa}

Oh mind! Sing on the Lord of golden stage-Kanakasabha (168-P).

\section{Śrīveṇugopālamibhajamānasasatatam}

Oh mind! Always sing on Shri Venugopala (294-P).

\section{Mānasa guruguha rūpaì bhajare re}

Oh mind! Sing on the form of Guruguha (111-P).

\section{Pavanātmajaṁ bhajare citta}

O psyche! Sing on the son of Vayu-Anjaneya (282-P).

\section{Tyāgarājaṁbhajarerecitta}

Oh, psyche! Sing on Tyagaraja (261-P).

\section{Dayānidhim bhajarehṛdaya satatam}

Oh! heart! Sing on Skandha, the ocean of mercy (109-P)(Govindarao.T, 1997).

\section{Various aspects of music}

Dikshitar talks about various aspects of music in his compositions and makes them the vital parts of his devotion.

\section{Gamapadādinutabhava}

You are glorified by the seven musical notes like Ga-Ma-Pa-Da etc (224-C).

\section{Bhāva Rāga tāla svarūpakam}

He is of the form of Bhāva -emotions, Rāga -melodies, Tāla -rhythm (424-C).

\section{Bhāvarāgatālaviśvāsin̄̄}

She reveals in music full of Bhāva -emotions, Rāga -melodies, Tāla-rhythm (430-C).

\section{BhāvaRāgatālamodin̄̄ì}

She exults full of Bhāva, Rāga and Tāla (431-C).

According to an Ancient Indian text 'Svara Śastra', The seventy-two Melakarta Rāgās (parent Rāgās) control the 72 important nerves in the body. It is believed that 
if one sings with due devotion, adhering to the Rāga Lakșanāa (norms) and Śruti Śuddhi (pitch purity) the Rāga could affect the particular nerve in the body in a favorable way Deekshitulu (2014) .

Among the composers of his time, Dikshitar was the first and only composer who had composed kṛtīs in all Melakarta Rāgās as he had adopted Venkațamakhī's classification of Rāgās Srivatsa (2001)

\section{Śaktipriyakarīì dvisaptatiRāgāàngaRāga Modinīìn}

She exults in the seventy-two Mela Rāgās and their Janya Rāgās-derivatives. At Thanjavur, Dikshitar decided to compose songs on different deities in all 72 Melakarta Rāgās and significantly to revive the rare Melakarta Rāgās like Chāyavati, Kiraṇāvali and others for his compositions on the deities in Thanjavur (468-C).

\section{Vīṇā and other musical instruments}

Dikshitar talks about various musical instruments and links them with Gods and Goddesses.

\section{Jhallīmaddala jarjharavādyanādamuditejñānaprade}

She takes delight in the music of instruments like Jhallī, Maddala, and jarjhara (226-C).

\section{Bherivịnāvenuvādine}

He enjoys playing Bherī, Vīṇā, and Veṇu (394-C).

Așțādaśa vādyādipriyam ati śuddhamaddala Sañgītaśāstrādi samyutam

He loves to hear eighteen kinds of vādyā's, likes the Śuddha Maddala and is enshrined in Sañgīta Sāastrā (128-C).

Though Dikshitar talks about various musical instruments his favorite is Vinnā. In his famous composition 'Bālagopāla' he refers to himself as'Vainika-Gāyaka', i.e, adept in playingVinnā and singing. He is the master of this instrument. He talks a lot about that.

\section{Vainika-Gāyaka guruguha nuta}

He is extolled by 'Vainika-Gāyaka' -Vīṇā players and songsters and Guruguha $(115-\mathrm{C})$.

\section{Dundubhivādyabhedanādavinodini vị̣̄̄̄ $\bar{a} d i n i$}

Takes delight in the sounds of many instruments like Dundubhi and who plays on Vịnā (181-AP)(Anupallavi).

\section{Vịna vādinyāin}

Who plays on the Vịnā (186-C).

Vịnā vādanotsukayā

Who delights in playing on the Viṇā (47-AP).

Vīnāvādana viduṣyā

Expert in playing Vīnā (20-P).

Vịnā gānadaśagamakakriye

Who plays ten kinds of Gamakas on the Vịnā (403-C). 


\section{Navaratnavīnā̄ōadinyāh}

Plays the Vīṇā bedecked with nine gems (331-C).

\section{Vallakīputakābhayavarada}

Saraswati, whose soft hands holds the Vallaki-Vīṇā (152-C).

After reaching Mantra Siddhī, Dikshitar was introduced to this unique Vīṇā as blessings from Goddess Ganga with the Yāli mukhi upwards and name of Shri Rama inscribed in Devanāgari on it. Dikshitar's compositions and the style of playing them on the Vinnā consists of the Sāhitya (lyrics) being speeded up by doubling the Akṣarās in a single round of Tâla where theTāla remains constant, this is the beauty of rendition of Dikshitar's compositions. Vinnā is one of the kind instruments where music can be played in an interval of eight tones Venkatarama (1968) .

The Madhyama-kāla Sāhityam (medium speed or tempo) is one of the decorative Angās (decorative tools) used by Dikshitar in his compositions and when observed resembles Tānam played on Vịnā. Kāla refers to the change of tempo during the rendition of the song, typically doubling the speed. The 'Tānam', a creative type of music in the Carnatic system is the elaboration of a Rāga in free rhythm in slow, medium, and fast tempo, and playing on the Vin̄a has evolved a unique style, peculiar to the Vinnā. To his mastery of Vinnā must be attributed to the adoption of Vilambakāla (slow speed or tempo) and the richness of Rāga-Bhāva in the Kṛtīs of Dikshitar. The beauty of the Rāga can be best brought out in slow measure, in a quick tempo many of the delicate shades of the Rāgā's are likely to be lost Jayanthi (2006).

\section{GAMAKAS}

Gamakas are subtle manipulations of notes also called as 'Ornamented note' in Sanskṛt and are described in Lakșaṇa Granthās, where words like 'Deflect' and 'Glide' are used. It signifies that the word 'Gamakam' originated from the techniques of playing the Vinna instrument. Matangamuni of Bṛhaddesi was the first to coin the word 'Gamakam' in his works. Gamakas involve the manifestation of the pitch of a note, using substantial and assertive vibrations between abutting and far-off notes. Dikshitar used ten different types of Gamakas also known as 'Daśagamakas'. Dikshitar referred to the Goddess Minakshi as 'Daśa gamaka kriyā' in his famous kṛti 'Minākși me mudam dehi" as she could spell ten Gamakas and portrayed her as Goddess 'Saraswati' since she plays Vịnā too.

Udupa (2000) .

Dikshitar used ten types of Gamakas : Ārohaṇā, Avarohan̄ā, Dhālu, Spuritha, Kampitha, Āhata, Pratyahatā, Thripucha, Āndolla, and Murchana are seen in his compositions.

The ten types of Gamakas are explained below:

1) Ārohanāa - A grace embracing notes in ascending order; s,r,g,m,p,d,n,s.

2) Avarohanā - Agrace inherent in the notes in the descending order; $\mathrm{s}, \mathrm{n}, \mathrm{d}, \mathrm{p}, \mathrm{m}, \mathrm{g}, \mathrm{r}, \mathrm{s}$.

3) Dhālu - It involves starting on a basic note and producing the higher notes in conformity with the Rāga Bhāva.

4) Spuritha - It is a Janța Svarā phrase wherein the lower note in between each Janța Svarā group is faintly heard. The second note of each Janța Svarā is stressed. 
5) Kampitha - Oscillation or shake that may be Dīrgha long or Hriśva (short).

6) Āhata - Anahatam means laya or beat. Ravva and Khandimpu are two types of Anahatam. This is played by striking the string on a note and immediately touching another note in a fleeting manner and coming back.

7) Pratyahatā - Agrace present in the Avarohanā Krama; 'sn, nd,dp, pm'.

8) Thripuca - One note occurring thrice i.e. Svarās in triplets; 'sss,rrr,ggg, mmm'.

9) Ândola- playing Svarās in the following manner; 'srsDd, srsPp, srsMm, srsGg'.

10) Murcana - starting on Śadja and proceeding regularly in the Ārohaṇā krama and finishing on the Dīrgha Niśāda and then starting on Rúabha and finishing on the Dīrgha Śadja; 'srgmpdN, rgmpdnS, gmpdnsR, mpdnsrG'.

Various Gamakas, graces, and other technically recognized musical accents in Carnatic music are based on nuances that appeared with the perfecting of the southern Vināa, owing to the nature of its strings, it can be played to give a percussion effect so Vịnā suits well to play Tāna Archana (2013) .

\section{TONES AND EMOTIONS}

A Rāga is a combination of particular svarās (notes) which provides the particular Bhāva (emotion) that a composer intended in a judicious combination and with a particular layā or rhythm providing a perception of immense joy. Since every Rāga is connected to a specific emotional theme called rasās, in each case a similar positive/elevated or negative/somber emotional theme is implied. This is called Mind-body medicine, for e.g, meditation, Yoga, visual imagery, group support, spirituality, and others.

A Sāhitya (composition) gives Rāga more importance than the words as the composition uses the Rāgā's and its gamakas to bring out the Bhāvā's (mood) of its Sāhitya (lyric). Various theories of characterizing Rāga's according to the sentiment, mood, emotion, season, ideal time i.e., can be sung during night or day, helped musicologists and composers to connect Rāga to a particular deity, or season or mood or even environment, based on the iconography of Rāgā's.

Bhāva or emotions encircles many facets like; Rāga Bhāva (emotions through the melody), Pada Bhāva (emotions in the phrase), Shabda Bhāva (emotions in the word) , Artha Bhāva (emotions in the meaning).

Dikshitar's compositions are Sthāyi Bhāva (emotionally stable) oriented and hence no room for Sanchāri Bhāva (temporary emotions). An emotionally stable and durable psychological state is an essential aesthetic aspect in Sanskrt theatrics which was later applied to Sanskrit literature. Bharata muni can be credited for the derivation of this concept who formulated the Rasa theory in Nātyaśāstra.

He added 8 Bhāvā's and later a ninth Bhāva called Śānta Bhāva. Abhinava Gupta states 'Transformation of Sthāyi Bhāva into rasa depends on the enjoyment capacity of the connoisseurs. Dikshitar kṛtīs dominate Śānta Bhāva. Dikshitar's compositions on deities are so vast and exclusive and devoid of any fabrication. They are perfect kṛti and not Nāmavalis or Bhajana Sāmpradāya. To summarise the usage of Bhāva by Dikshitar they are somber, composed, and they justify in his compositions Krishnan (2006) .

Rāgas (tones) are extremely important in Indian classical music. Carnatic Music has maximum varieties in Rāgas. Dikshitar is expert in Rāgas. His compositions not only communicate several emotions to us with their literature but also through their 
Rāgas. Dikshitar is very particular and careful regarding choosing Rāgas for his compositions.

E.g. Rāga Hamsadhwani is a Vīra Rasa Rāga (Heroic in nature), significant feature with Bhāvās of enthusiasm, courage, good thinking, and spirited. The absence of Madhyama and Daivata svarās creates vacuum zones leading to the calmness of mind. The absence of Madhyama svara gives the power to detach attachments providing emotional control and intellectual stability. The absence of Daivata svara gives occult powers. This Rāga makes us feel grounded and emotionally stable. The speciality of the song is the significance of number ' 5 '; the raga is audhwa raga with 5 main swaras (sa, ri, ga, pa, ni), panch pranas, panch bhootas. Ganapati is extolled as grandeur, sign of prosperity and graceful.

Combining the two aspects the song that starts with Vātāpi ganapatim bhaje is sung in Rāga Hamsadhwani as the features of the Rāga are emotional stability, courage, enthusiasm, good thinking, necessary when we start something auspicious where detachments from worldly desires are necessary to attach with the Almighty. This Rāga is called 'Sarva kālika Rāga', can be sung at any time and 'Maṇgala kara Rāga', very auspicious in nature. Dikshitar may have considered these features and composed the song in Rāga Hamsadhwani which was discovered by his father Ramaswami Dikshitar (334) Madhavi (2017) .

Rāga Gamakakriya is usually sung in 'Dīna' (helpless situation). Gamaka (embellishment done between two notes in music) is important in this Rāga. According to Dikshitar, the ten Gamakas mentioned in the composition can be either sung or played on the Viṇā. Gāndhāra Jīvasvara (the main note) has to be repeated occasionally. These two features of this Rāga make to induce melancholic mood. Dikshitar got an intuition that he was nearing his end. Being a Devi Upāsaka, Dikshitar knew that if he prayed to the goddess, she would grant him liberation and free the spirit from the bondage of desires. He surrenders finally expressing the emotion of a selfless situation through this Rāga. We can the serious depth of devotion in this song as she is extolled with various names like pashamochini, kadamba vasini, madhura puri nilaye as the names creates a blissful feeling.

In Bhakti Yoga when one expresses his helpless situation and surrenders to the Divine, with all his layers of personality starting from his physique to intellect, he gets liberated from all his adjuncts. Dikshitar sings the song starting with 'Minakși me mudam dehi' in Rāga Gamakakriya, expressing his helplessness and ultimate trust in the Divine through this Rāga and surrenders to the Divine (403).

Rāga Śrī is auspicious that signifies the conclusion of any concert or any sacred ritual. This Rāga is also sung to seek forgiveness for any mistake that may have crept during the performance. This Rāga is said to ward off all the errors and bestow Mangalam (auspiciousness) and wellness. It exemplifies the divine union and conferring boons to all creations. The Rāga suits the script indicating the merging of all five elements in the Divine indicating the presence of supreme consciousness everywhere. Dikshitar sings the song starting with Śrī Kamalāmbike śive pāhi mām lalite to make an effective conclusion in Navavaraṇa Kṛti (140).

Dikshitar has sung the song that starts with Anandamrutakarshini in Rāga Amrutavarshini which means pouring of nectar or showers of rain. It is believed that this Rāga alleviates diseases related to heat. This Rāga is a classical piece with Bhāvas or emotions associated with a joyful and passionate appeal to the goddess of rain in the form of prayers where the svara combinations created a legend by pouring down rains. It answered Dikshitar's prayers, providing water to the parched lands and thirsty people of Ettayapuram (459) 
The famous kriti 'Ramachandram bhavayamiin' in raga Vasanta is a soulful and melodious song felt through the swaras of the raga and also gives the soothing feeling like the waves of cold river. The pallavi, anupallavi, charanam gives the feeling of a cool breeze when listened closing the eyes and since the Madhayamakala sahityam is a bit speeder which remains as the asset of the song. The raga creates a feeling of peace while thinking over the personality of lord Rama Acharya (2000) .

\section{CONCLUSION}

Muthuswami Dikshitar can be considered as the pioneer of both fusion music and Raga chikitsa since his compositions follow the stotra tradition (chanting of mantras). The chanting and toning involved in Veda hymns in praise of God has been used to cure several disharmonies in the individual and enhances immunity. His kritis were appropriately and systematically organized into different sects or groups i.e. sthala group, deity group, sub-group of ragas, and kritis depicting the temple architecture. The thorough scientific knowledge Dikshitar acquired in music helped him to properly handle ragas and discover their intrinsic and hidden beauty which created fusion music like'Vibhakti kritis'. When the eternal milky ocean of music was churned, Dikshitar dived deep and brought out corals and pearls. The eternal sweetness of coconut water, which is attained after removing confusion, the negativity of the husk and breaking the hard shell of the ego, to merge into the supreme state of ananda (bliss) this being the main quality of his music. His krtis are complex yet very melodious. All his kritis represent the 'Raga-Devata' installed by him in the sanctum sanctorum is worshipped through rituals that constitute the 'Ragaswarupa'.

\section{REFRENCES}

Acharya, S. (2000). Karnataka Sangeet Deepika.

Archana, M. V. (2013). Karnataka Sangeetada Rachanegallali Sri Vidyeya Ullekha.

Deekshitulu, B. (2014). Stress Reduction Through Listening Indian Classical Music. Innovare Journal of Health Sciences, 2(2), 4-8.

Govindarao, T. (1997). Compositions of Muthuswami Diksitar. In Biography on the Translation Works of Muthuswami Dikshitar Gyanamandir Publications.

Jayanthi, R. (2006). Analytical Study of the Different Banis And Techniques of Playing the Saraswathi Veena. The University Of Mysore.

Krishnan, S. (2006). Muthuswami Dikshitar and Tiruvarur. In Autobiography The C.P. Ramaswami Aiyar Foundation.

Madhavi, V. (2017). Sangeet Shastra Mandakini. In 2nd Book, 290.

Shivashankari, J. (2015). Sri Muthuswami Dikshitar Compositions on Goddess Saraswatī. IOSR Journal Of Humanities And Social Science, 20(9), 28-32.

Sreeranjini, M. (2010). Analysis of the Compositions of Sri Muthuswami Dikshitar With Special Reference To Lord Siva. Sree Sankaracharya University of Sanskrit, 317.

Srilekha, P. (2016). Charana Structures in the compositions of Sri Muthuswami Dikshitar. Shodhganga. University of Calicut. 
Srivatsa, V. (1995). Bhava Raga Tala Modini. In Guruguhanjali (Ed.), Muthuswami Dikshitar Compositions 83.

Srivatsa, V. (2001). A Shashtiabdapoorti Bouquet. In Bio-Sketch Ms Maithreyi Ramadurai. 276.

Udupa, A. (2000). GuruGuha Gana Vaibhava. In Chennai-17 (Ed.), The complete works of Dikshitar in Kannada.

Aiyar, T. L. V. (1968). Muthuswami Dikshitar. National Book Trust, India, 78. 